\title{
The Delay Simulation on Hierarchical Structure for Semi- Double Track of Railway Line Using Max-Plus Algebra
}

\author{
Tri Utomo ${ }^{1}$, Eristia Arfi ${ }^{1}$ \\ ${ }^{1}$ Mathematics Department, Institut Teknologi Sumatera, Lampung Selatan
}

\begin{abstract}
The persistently inequality of development between major cities and surrounding areas caused the displacement process, that are transport of supplies or human itself (urbanization) or commonly known as the transportation. The government has set a number of policies to overcome transportation problems, for example construct a double track railway line. This study aimed to find an alternative solution to overcome the problems of transportation, especially railway line by optimizing of using single track railway line which is given the term semi-double track using Petri Nets and Max-Plus Algebra. In the previous research, a Max-Plus algebra model has been developed based on the hierarchical structure of semi-double track railway line. In this research, the model is simulated against the problem of delay.
\end{abstract}

\section{Introductions}

One of the problems faced by Indonesia today is the transportation, that can be seen in land transportation, there are a lot of congestion everywhere which requires to find solutions to overcome them. In this case, land transportation can be overcome by diverting transportation to mass transportation modes, such as trains. Regarding this matter, the government has set several policies related to railways, one of them is the construction of double track railway line.

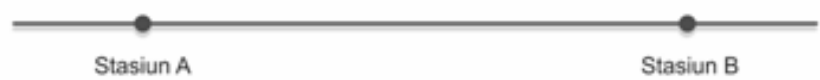

(a)

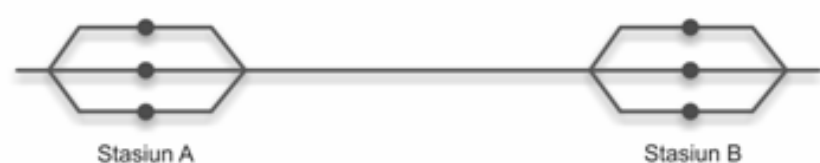

(b)

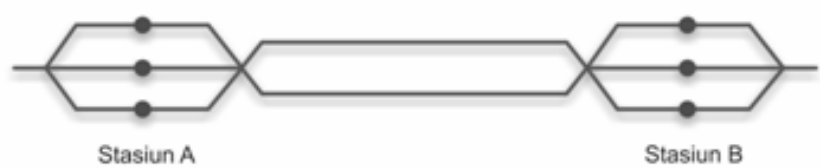

(c)

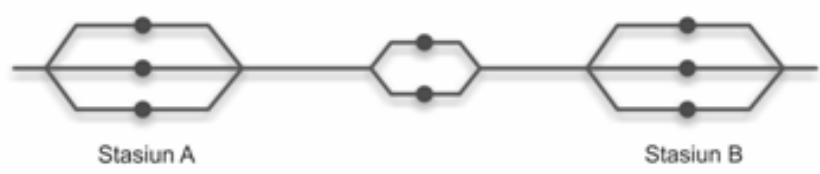

(d) 
Figure 1. Illustration of the railways line (a) illustration of two stations using a graph, (b) Illustration of single-track railway line, (c) Illustration of double-track railway line, (d) Illustration of semidouble-track railway line

From the explanation above, this research is intended to find an alternative solutions to overcome the problems of transportation, especially in railways, by using Petri Net and Max-Plus Algebra as modeling tools. The idea of this research is to optimize the use of a single track railway line by adding intersections in the middle of the railway line between two main stations, which is given the term semi-double track railway line, as an illustration can be seen in Figure 1.

The problems on semi-double track railway line are how to determine the hierarchical direction of the track. That is due to the division of resources alternately for several trains passing through it. Unlike the double track railway line, we can directly determine the direction of the different direction for each resource. Similar problems have been discussed by [1].

This research is a squel of previous research conducted by Tri Utomo and Subiono [2] [3]. In this further research is carried out on that Petri Net and Max-Plus Algebra models that have been constructed in previous studies, that is about the delay simulations.

\section{Literature Review and Basic Theory}

\subsection{Literature Review}

There are several studies related to scheduling system problems using Max-Plus Algebra, for example on bus, train, and airplane departure scheduling systems. On bus scheduling systems was done by [4] and [5]. The research related to aircraft scheduling was carried out by [6]. Researches related to train scheduling have also been carried out by [7] and [8]. However, studies on train scheduling discuss without seeing the railways line used, which is single track or double track. This study is discuss related to the problem of scheduling trains by considering the railway lines used.

\subsection{Basic Theory}

Petri Net is a bipartition graphs, which consists of two subsets of $P$ and $T$. $P$ is set of places and $T$ is set of transitions. Petri Net is a mathematical modeling and scheduling tool that is easily applied to many systems, for example to explain and describe informations, or the process of a system. Petri Net can be written as 5-tuple $\left(P, T, F, W, M_{0}\right)$ [9], where

$P=\left\{p_{1}, p_{2}, \ldots, p_{m}\right\}$ is finite set of places,

$T=\left\{t_{1}, t_{2}, \ldots, t_{n}\right\}$ is finite set of transitions,

$F \subseteq(P \times T) \cup(T \times P)$ is set of arcs,

$W: F \rightarrow\{1,2,3, \ldots\}$ is set of weight,

$M_{0}: P \rightarrow\{0,1,2,3, \ldots\}$ is the initial marking,

$P \cap T=\varnothing$ and $P \cup T \neq \varnothing$.

Whereas Max-Plus Algebra is an algebraic structure consisting of $R_{\epsilon}$ where $R_{\epsilon}=R \cup\{\epsilon\}$ and $\epsilon=-\infty$ together with two binary operators that are Operator Max $(\bigoplus$ "read: oplus") and Operator Plus $(\otimes$ "read: otimes"), Which is defined as follows, $\forall x, y \in R_{\epsilon}, x \oplus y=\max \{x, y\}$ and $x \otimes y=x+y$. It is known that $\left(R_{\epsilon}, \oplus, \otimes\right)$ is semi-ring with neutral elements $\epsilon$ and unit elements 0 [10]. 


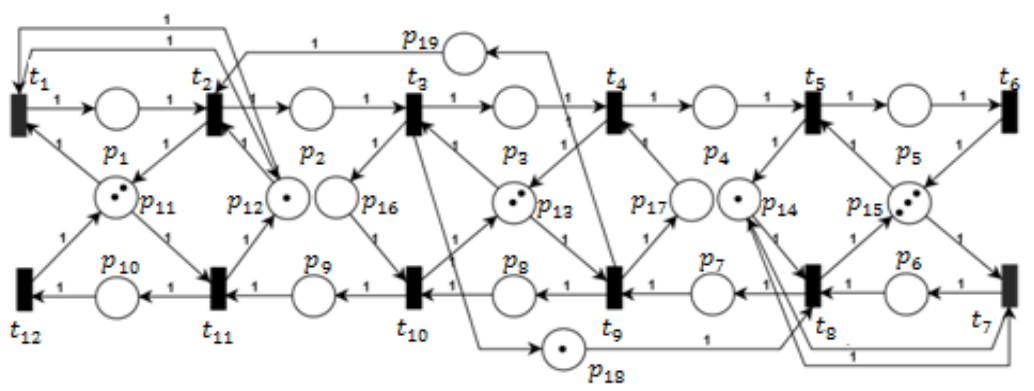

Figure 2. Petri Net Model with Priority

\section{Main Results}

\subsection{Model of Petri Net and Max-Plus Algebra}

Based on previous research [2], we obtained the Petri Net model with the priorities. This Petri Net model is is constructed by considering the order of priority, thus forming a hierarchical structure in the direction of the railway line track. Thus the bottleneck can be avoided at any time, consider Figure 2

In addition, the Max-Plus Algebra model is based on the Petri Net model in Figure $\mathbf{2}$ as follows.

$$
\tilde{\boldsymbol{t}}(k+1)=\tilde{A}(k) \otimes \tilde{\boldsymbol{t}}(k)
$$

with

$$
\tilde{A}=\left[\begin{array}{cccc}
A_{0}^{*} \otimes A_{1} & A_{0}^{*} \otimes A_{2} & A_{0}^{*} \otimes A_{3} & A_{0}^{*} \otimes A_{4} \\
E & \mathcal{E} & \mathcal{E} & \mathcal{E} \\
\mathcal{E} & E & \mathcal{E} & \mathcal{E} \\
\mathcal{E} & \mathcal{E} & E & \mathcal{E}
\end{array}\right]
$$

and

$$
\tilde{\boldsymbol{t}}(k)=\left[\boldsymbol{t}^{\prime}(k), \boldsymbol{t}^{\prime}(k-1), \boldsymbol{t}^{\prime}(k-2), \boldsymbol{t}^{\prime}(k-3)\right]^{\prime}
$$

Equation (1) is the Max-Plus Algebra model formed from Petri Net model Figure 2. For simulations of the Max-Plus Algebra model, the Petri Net and Max-Plus Algebra toolboxes are used in the Scilab. If the travel time or the train from SDA (Sidoarjo Station) to the GDG (Gedangan Station) is 8 minutes, and the travel time from the GDG to WR (Waru Station) is 4 minutes, and the waiting time of the train at each station is 2 minutes, it is found that eigenvalue $\lambda=26$. This shows that it takes 26 minutes for the train that travel in the same direction to travel in the next cycle from the previous departure at each station.

\subsection{The Delay Simulations}

In this section a simulation of the system is reviewed if some trains are delayed. suppose the arrival of the $k$-th train has been delayed. The first from SDA to GDG was delay for 18 minutes, second from WO (Wonokromo Station) to WR for 8 minutes, and from GDG to SDA for 19 minutes. In addition, the $k$ th train departure from the WR to WO is delayed by 4 minutes, and from SDA to BG (Bangil Station) for 2 minutes. Likewise with the departure of $(k-1)$-th trains from WR to WO there was a delay of 9 minutes.

By doing a simulation using the Petri Net and Algebra Max-Plus toolbox in the Scilab, it was found that the delayed arrival and departure of the $k$-th train in each station will result in delayed arrivals or departures of the $(k+1)$-th train at other stations. But the value decreases and will go to zero. This means that on the arrival or departure of the next train there is no delay. In this case it can be concluded that the Max-Plus Algebra model in Equation (1) is stable. 


\section{Acknowledgments}

The author would like to thank Institut Teknologi Sumatera (ITERA), which has provided funding in conducting this research in the form of the "Hibah Mandiri ITERA 2017 research grant".

\section{References}

[1] L. Danjing and Magdeburg, A Hierarchical Control Structure for A Class of Timed Discrete Event Systems, Dissertation of Electrical Engineering and Computer Science, Technical University of Berlin, 2008.

[2] T. Utomo and Subiono, "Struktur Hirarkis Jalur Kereta Api SDT Menggunakan Petri Net dan Aljabar Max-Plus," in Semnastika 2015, Surabaya, 2015.

[3] T. Utomo and Subiono, "Struktur Hirarkis Jalur Kereta Api Semi-Double Track Menggunakan Petri Net dan Aljabar Max-Plus," Thesis of Magister Programs, Institut Teknologi Sepuluh Nopember, Surabaya, 2015.

[4] K. Oktafianto, "Implementasi Aljabar Max-Plus pada Pemodelan dan Penjadwalan Keberangkatan Bus Kota Damri (Studi Kasus di Surabaya)," Thesis of Bachelor Programs, Institut Teknologi Sepuluh Nopember, Surabaya, 2013.

[5] K. Fahim, "Aplikasi Aljabar Max-Plus pada Pemodelan dan Penjadwalan Busway yang Diintegrasikan dengan Kereta Api Komuter," Thesis of Bachelor Programs, Institut Teknologi Sepuluh Nopember, Surabaya, 2013.

[6] D. A. Anggraeni, "Analisis Jadwal Keberangkatan Pesawat Transit di Bandara dengan Menggunakan Aljabar Max-Plus," Thesis of Bachelor Programs, Institut Teknologi Sepuluh Nopember, Surabaya, 2013.

[7] S. Alfiah, "Pemodelan Jaringan Kereta Rel Listrik (KRL) Menggunakan Aljabar Max-Plus," Thesis of Magister Programs, Institut Teknologi Sepuluh Nopember, Surabaya, 2011.

[8] F. A. N. F. Afiatna, "Pemodelan dan Penjadwalan Monorel dan Trem yang Terintegrasi di Kota Surabaya Menggunakan Aljabar Max-Plus," Thesis of Bachelor Programs, Institut Teknologi Sepuluh Nopember, Surabaya, 2013.

[9] T. Murata, "Petri Nets: Properties, Analysis and Applications," in Proceding of The IEEE, 1989.

[10] Subiono, Aljabar Min-Max Plus dan Terapannya, Surabaya: Buku Ajar Mata Kuliah Pilihan Pascasarjana Matematika Institut Teknologi Sepuluh Nopember Surabaya, 2015. 